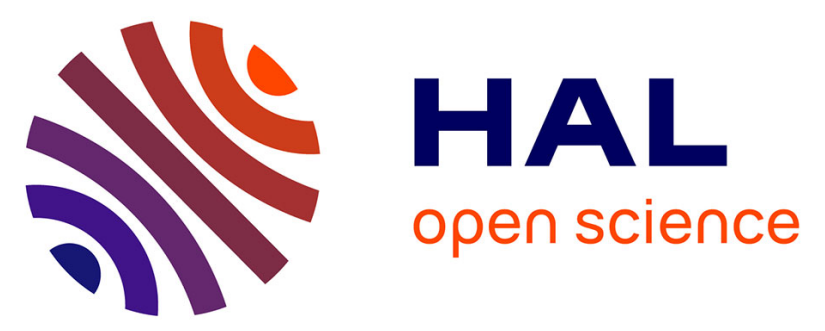

\title{
Lathe check development and properties: effect of log soaking temperature, compression rate, cutting radius and cutting speed during peeling process of European beech (Fagus sylvatica L.) veneer
}

Anti Rohumaa, Joffrey Viguier, Stéphane Girardon, Michael Krebs, Louis

Denaud

\section{To cite this version:}

Anti Rohumaa, Joffrey Viguier, Stéphane Girardon, Michael Krebs, Louis Denaud. Lathe check development and properties: effect of log soaking temperature, compression rate, cutting radius and cutting speed during peeling process of European beech (Fagus sylvatica L.) veneer. European Journal of Wood and Wood Products, 2018, 6, pp.22. 10.1007/s00107-018-1341-9 . hal-01894957

\section{HAL Id: hal-01894957 \\ https://hal.science/hal-01894957}

Submitted on 13 Oct 2018

HAL is a multi-disciplinary open access archive for the deposit and dissemination of scientific research documents, whether they are published or not. The documents may come from teaching and research institutions in France or abroad, or from public or private research centers.
L'archive ouverte pluridisciplinaire $\mathbf{H A L}$, est destinée au dépôt et à la diffusion de documents scientifiques de niveau recherche, publiés ou non, émanant des établissements d'enseignement et de recherche français ou étrangers, des laboratoires publics ou privés. 


\title{
Lathe check development and properties: effect of log soaking temperature, compression rate, cutting radius and cutting speed during peeling process of European beech (Fagus sylvatica $L$.) veneer
}

\author{
Anti Rohumaa ${ }^{1,2 *}$, Joffrey Viguier ${ }^{1}$, Stéphane Girardon ${ }^{1}$, Michael Krebs ${ }^{1}$, Louis Denaud ${ }^{1}$ \\ ${ }^{1}$ LaBoMaP, École Nationale Supérieure d'Arts et Métiers (ENSAM), Cluny, 71250, France \\ ${ }^{2}$ FiberLaboratory, South-Eastern Finland University of Applied Sciences, Savonlinna, 57200, \\ Finland
}

*Corresponding author.

LaBoMaP, École Nationale Supérieure d'Arts et Métiers (ENSAM), Cluny, 71250, France

E-mail: anti.rohumaa@gmail.com

\begin{abstract}
The depth of lathe checks and integrity of veneer have been shown to be critical factors affecting the bonding process but also affecting the mechanical properties of veneer-based products. This study shows how beech (Fagus sylvatica L.) veneer lathe checks interval and depths are affected by soaking temperature, compression rate, cutting radius and cutting speed during the peeling process in well-controlled conditions. Freshly felled European beech logs were soaked in a water tank at $50,60,70$ or $80^{\circ} \mathrm{C}$. Following soaking, the logs were immediately peeled with laboratory scale lathe (SEM S500) to $3.5 \mathrm{~mm}$ thick veneer at a cutting speed of 1,2 or $3 \mathrm{~m} \mathrm{~s}^{-1}$ and pressure rates of $0,5,10$ or $15 \%$. The correlation between lathe check depth and frequency was validated using "Système de Mesure d'Ouverture des Fissures" (SMOF) device, which enables to measure check properties reliably on veneer ribbons. In a well-controlled peeling process, the strong correlation between check depth and interval was shown. At higher temperature, shallower and more frequent checks are created compared to lower temperature. However, the effect of soaking temperature (between $50-80^{\circ} \mathrm{C}$ ) on veneer checking is much smaller than the effect of compression rate during peeling process, where the higher compression rate produced veneer with shallower and more frequent checks. The results of the study also show that the direction of lathe check propagation could be affected by the rays in beech veneer. Rays resist crack growth in tangential direction, but act as weak planes in radial direction.
\end{abstract}




\section{Introduction}

Adhesive bond formation and performance in veneer-based products is highly dependent on the veneer quality used, which is formed through the multistage mechanical processing of the wood material. One of these process stages is soaking, where the logs are commonly heated prior to peeling in order to soften the wood (Sellers 1985; Marchal et al. 2009; Dupleix et al. 2013) so as to obtain smoother veneer and minimise the severity of knife checks (Meriluoto 1965; Dupleix et al. 2013). Generally, at higher temperature during peeling the formation of deep lathe checks will be reduced (Meriluoto 1965; Dupleix et al.2013) and the integrity of the veneer will be improved (Rohumaa et al. 2016a). The depth of checks and integrity of veneer have been shown to be critical factors affecting the bonding process (Rohumaa et al. 2013, 2014, 2016b), but also have effect on veneer based products shape stability and mechanical properties (Blomqvist et al. 2014; Pot et al. 2015).

The effect of soaking on veneer quality cannot be observed as a separate process in the veneer production, because the subsequent peeling process forms the veneer surface. In the peeling process, it has been noted that the compression rate affects the depth and frequency of lathe checks (Lutz 1974); with low compression the rough veneer and deep lathe checks could be formed and with high pressure the spin outs and the tearing of grain could occur (Spelter 1991). According to the literature (Leney 1960), the lathe check phenomenon is almost constant when it is well established, and for homogeneous wood species it could be periodical (Denaud et al. 2012; Palubicki et al. 2010). Moreover, the lathe checks are supposed to not vary too much as a function 
of peeling radius except for very low radius where the presence of juvenile wood (exhibiting different mechanical properties) could change the behaviour of the veneer (Darmawan et al. 2015). Generally, lathe check properties such as depth and frequency correlate with each other; deeper checks tend to be less frequent than shallower checks (McMillin 1958; Denaud et al. 2007; Pałubicki et al. 2010). However, some studies show opposite results (Darmawan et al. 2015) suggesting that the check frequency will decrease with higher soaking temperature. These contradictions in published results highlight that there are still open questions about the role of processing in lathe check formation. Variation and contradiction in results could be caused by many variables, such as different measuring techniques, processing parameters, wood species, etc.

Lathe check formation and measurement during peeling process have received a lot of attention in the past as well as more recently (Denaud et al. 2007, 2012; Tomppo et al. 2009; Pałubicki et al. 2010; Dupleix et al. 2013; Antikainen et al. 2015; Darmawan et al. 2015). Lathe check depth (LCD) has been measured traditionally by dyeing and evaluating under the microscope (Lutz 1960, 1978) in order to identify their effect on product quality (Rohumaa et al. 2013; Pot et al. 2015). However, microscopic measurements are time-consuming, laborious, and typically only a limited amount of specimens is evaluated during study, which might explain the dispersion in obtained results.

To automatize the LCD measurement process for online measurement, the checks have to be measured from the green veneer since measuring checks from the dry veneer is complicated due to the waviness of the veneer (Tomppo et al. 2009). Moreover, check properties should be measured immediately after peeling to give a comprehensive overview on check properties and to 
enable quick response back to the process. During this study, the further development of SMOF, a semi-automated system designed to measure lathe checks in veneer ribbon, presented by Pałubicki et al. (2010) has been done, which will enable to evaluate remarkable amount of checks automatically immediately after the peeling process. Moreover, it will enable to measure precisely all checks and their parameters through the whole mat of veneer peeled.

This study shows how beech veneer lathe check frequency and depth are affected by soaking temperature, compression rate, cutting radius and cutting speed during the peeling process in wellcontrolled laboratory conditions with a large number of samples evaluated with SMOF.

\section{Materials and methods}

\section{Veneer material preparation}

In this study, nineteen (19) European beech (Fagus sylvatica L.) logs with a maximum diameter of $520 \mathrm{~mm}$ were prepared from two trees freshly felled from the public forest of Cluny (France). The material was selected carefully and only material without visual defects was used. Table 1 shows the full experimental design. The logs were soaked in a water tank until their whole volume reached the target soaking temperature, which was set to $50,60,70$ or $80^{\circ} \mathrm{C}$. This range of temperature corresponds to the common distribution also used in industry. Following soaking, the logs were immediately peeled. An instrumented light packaging scale lathe (SEM S500 - Knife length $900 \mathrm{~mm}$ ) equipped with an angular pressure bar was used to peel $3.5 \mathrm{~mm}$ thick veneer with a cutting speed of 1,2 or $3 \mathrm{~m} \mathrm{~s}^{-1}$. The thickness was set to $3.5 \mathrm{~mm}$, since it is a common thickness used to produce Laminated Veneer Lumber. The compression rates used in this study were 0, 5, 
10 , or $15 \%$ of veneer nominal thickness and this range of compression rates from 0 to $15 \%$ is expected to form remarkable differences in lathe check properties. Immediately after peeling, veneer ribbons were cut along the whole obtained veneer mat with a width of approximately 80 $\mathrm{mm}$. One edge of the veneer ribbon was planed to reveal the checks and to enable their reliable detection and measurement.

The LaBoMaP has developed a specific apparatus, called SMOF (Système de Mesure d'Ouverture des Fissures), to measure lathe check parameters. The principle of SMOF operation is described in detail by Palubicki et al. (2010). The SMOF enables to measure automatically and precisely the position and the depth of a large number of checks by slightly bending the veneer on a wheel with previously approved diameter. Below Figure 1 presents the SMOF specifically adapted for this study. Different to the SMOF used by Palubicki et al. (2010), modified SMOF has a larger wheel $(\mathrm{d}=180 \mathrm{~mm})$, which was chosen to measure shallow checks without increasing their depth.

Moreover, the objective of the camera has also been changed to improve the field depth. Finally, the initial algorithm of measurement was completely modified to optimize the automatic detection of the check parameters as presented in Figure 2. New software was designed to improve the robustness of the data treatment. The resolution in length and width of the veneer is equal to $0.08 \mathrm{~mm}$.

In addition, SMOF will enable the precise measurement of veneer thickness performed with the linear variable differential transformer (LVDT) sensor shown in Figure 1.

\section{Data Analysis}


Lathe check depth (LCD) is calculated by comparing the detection of the end of the check to the thickness measured by the LVDT sensor. Distances between checks are calculated only on the horizontal component of the end of the checks. Everything was therefore performed using Matlab (MathWorks, R2012a, Natick, USA). Statistical analysis was made using the Matlab built-in functions "anova1" and "multcompare".

\section{Results and discussion}

\section{The effect of log cutting radius on lathe check properties}

In first part of the study, preliminary test was performed with the wood material soaked at $70^{\circ} \mathrm{C}$ and peeled with a compression rate of $0 \%$ to $3.5 \mathrm{~mm}$ thick veneer. The veneer mat was cut into sheets with dimensions $600 \times 750 \mathrm{~mm}^{2}$. From each veneer sheet, a veneer ribbon was sawn with a width of approximately $80 \mathrm{~mm}$ and characterized with the SMOF. The results show that the median check interval (Figure 3a) and the check depths (Figure 3b) are almost constant through the whole length of the veneer mat. Plot box markers from top to bottom represent the maximum, the third quartile (q3), the median, the first quartile (q1) and the minimum value. Values considered as outliers are marked with the cross. Points are considered as outliers if they are larger than q3 + $\mathrm{w}(\mathrm{q} 3-\mathrm{q} 1)$ or smaller than $\mathrm{q} 1-\mathrm{w}(\mathrm{q} 3-\mathrm{q} 1)$, where the factor $\mathrm{w}$ is equal to 1.5 and it corresponds to $+/-2.7$ times the standard deviation and $99.3 \%$ coverage of data. The coefficient of variation for all measured lathe check intervals is low (3.8\%) and for the lathe check depths the coefficient of variation is $7.6 \%$. This check test contains more than 4000 check evaluations and can be considered statistically representative of the process. 
The results obtained from the whole length of the veneer ribbon also show remarkable scattering in individual measurement results. Depending on the techniques used, all checks might not be visible and properly revealed in order to detect and measure; hence this could also be one of the reasons for remarkable scattering in interval and the depth results obtained previously by other researchers (Dupleix et al. 2013; Darmawan et al. 2015).

\section{The effect of log cutting speed on lathe check properties}

In second part of the study, the effect of cutting speed on lathe check properties was evaluated. The veneer was prepared under the same conditions as the material described in the previous section for the log radius study. The only variable was cutting speed, which was 1,2 or $3 \mathrm{~m} \mathrm{~s}^{-1}$. Further, in this part of the study, the whole length of the veneer mat was examined for lathe check properties.

The results of the study show that cutting speed does not have a critical effect on lathe check parameters (Figure 4). As shown in Figure 4, lathe check depth and frequency show a slight decrease in mean values with increasing peeling speed; however, statistically there are no differences based on ANOVA analysis. These results support previous observations made by Lutz (1978) where cutting speed in the range of 50 to $150 \mathrm{~m} \mathrm{~min}^{-1}$ has shown not to affect veneer quality. Moreover, the results of this study show that there are no differences in check properties below the cutting speed $180 \mathrm{~m} \mathrm{~min}^{-1}$.

\section{The effect of soaking temperature and compression rate on lathe check properties}


In third part of the study, the effect of soaking temperature and compression rate on lathe check properties was evaluated. An image of the side of the veneer was acquired (Figure 5), and the check depth and frequency were automatically evaluated by SMOF (Figure 2).

Figure 5 shows that the lathe check depth is highly influenced by compression rate where the higher pressure shows to form shallower checks, which could be sometimes hard to detect visually. Comparison of obtained images (Figure 5a-5d) also shows that at higher soaking temperature (Figure 5c, 5d) and higher compression rate (10 - 15\%) checks are visually almost undetectable and non-periodical. On the other hand, at lower soaking temperature $\left(50\right.$ or $\left.60^{\circ} \mathrm{C}\right)$ and at higher compression rate deeper and periodical checks are formed. These images also support previously described finding, where some of the checks could not be revealed for visual or automatic detection and therefore, increase scattering of measured results.

Buchelt et al. (2018) noticed that the crack propagation could be influenced by structural elements, like large vessels or rays. In addition, the observations of this study show that check propagation in beech is affected by anatomical features like rays. On visual observation it was noticed that at lower soaking and peeling temperature checks might often change direction and start to propagate along the rays (Figure 6a); oppositely at the higher temperature the checks often pass through the rays as demonstrated in Figure $6 b$.

The correlation between lathe check depth and frequency was validated using SMOF. The results show that for deeply checked veneers (depth about $2 / 3$ of the thickness) a relatively low number of checks per veneer meter was observed, contrary to shallow checks (depth about 1/4 of the thickness) where numerous checks were created. Figure 7 shows that strong correlation between 
check depth and frequency was observed, where the coefficient of determination $\mathrm{R}^{2}$ between the median check interval and the median check depth was equal to 0.81 .

Figure 8a shows lathe check interval measured between two consecutive checks and Figure 8b shows lathe check depth measurement results for all ribbons of veneers. The distribution of depths is large since the effect of the anatomy and the detection accuracy seems to be important. However, the number of checks measured in this study (about 20 000) largely exceeds the amount of checks measured in previous studies by other researchers and due to that constitutes a very strong reference data base.

The results show that the effect of compression rate on checks is absolutely clear: the higher the pressure, the shallower and more frequent the checks are. The pressure bar has definitely a decreasing effect on lathe check depths. It is also interesting to note that the distribution of measured intervals seems to increase with the use of pressure bar. Hence, when the lathe checks are shallow, as in the test group soaked at $80^{\circ} \mathrm{C}$ and peeled with $15 \%$ compression, some areas could be left unchecked or checks are not easily revealed. On the other hand, when cutting conditions are favourable to lathe checking (soaking at $50^{\circ} \mathrm{C}$ and peeling with $0 \%$ compression) the checks are easily revealed and are periodical with smaller distribution (Figure 8a). The effect of soaking temperature seems to be not remarkable on lathe check interval (Figure 8a). However, comparing this study with other studies conducted under similar conditions (Dupleix et al. 2013; Rohumaa et al. 2016a), some interesting observations could be made. The results show that the rise of soaking temperature from $50^{\circ} \mathrm{C}$ to $80^{\circ} \mathrm{C}$ will have a decreasing effect on lathe check depths, which is approximately $15-20 \%$. Similar values for beech were also obtained by Dupleix et al. 
(2013). Interestingly, much higher decrease of lathe check depths was observed on birch (Dupleix et al. 2013; Rohumaa et al. 2016a), showing that soaking temperature has a much more significant effect on birch than on beech by decreasing the depth of checks by approximately $30-35 \%$ in the same range of temperature. The reason might lie in the different anatomical structure, where beech has much higher volume of rays (approx. 20\%) compared to birch (approx. 10\%). Rays have been shown to resist crack growth in tangential direction (Boatright and Garrett 1983) but act as weak planes in radial direction (Ashby et al. 1985). These findings also support the results obtained in this study, where the lathe checks will more favourably propagate along the rays (radial direction) at lower temperature (Figure 6a) and will pass through the rays (Figure 6b) at higher temperature. This weaker plane caused by rays in radial direction will also explain the deeper checks compared to the results on birch wood obtained by Dupleix et al. (2013) and Rohumaa et al. (2016a).

\section{Conclusion}

The correlation between lathe check depth and frequency was validated using SMOF device with a very large amount of data (over 20000 ). Check properties are varying inside the same veneer, but with a remarkable amount of obtained data the check parameters can be reliably measured and properties evaluated. In well-established peeling process the strong correlation between checks depth and frequency was shown.

At higher temperature shallower and more frequent checks are created, compared to lower temperature. However, the effect of soaking temperature (between $50-80^{\circ} \mathrm{C}$ ) on veneer checking is much smaller than the effect of compression during peeling process, where the higher compression produced veneer with shallower and more frequent checks. When focussing only on 
lathe check phenomenon, optimal peeling setting was obtained at 70 and $80^{\circ} \mathrm{C}$ of soaking and at a compression rate of $15 \%$. Proposed settings will produce very shallow checks. However, lathe checks are not the only criteria to produce good quality veneer.

The results also show that check parameters are varying inside the same veneer sheet and it can be challenging to measure all checks. Moreover, some of the checks just cannot be visible and due to that could increase deviation in results obtained by different authors and methods that are used previously.

The results of the study also show that in beech veneer the direction of lathe check propagation could be affected by the rays. Rays resist crack growth in tangential direction but act as weak planes in radial direction. Moreover, at higher temperature checks most likely will pass through the rays, but at lower temperature the checks will change their direction and start to follow the rays, which will affect check depth and shape and in turn also bonding quality.

\section{Acknowledgements}

The authors gratefully acknowledge the financial support from the Bourgogne Franche-Comte region and Pollmeier. The authors would also like to thank the Xylomat Technical Platform from the Xylomat Scientific Network funded by ANR-10-EQPX-16 XYLOFOREST.

\section{References}

Antikainen T, Eskelinen J, Rohumaa A, Vainio T, Hughes M (2015) Simultaneous measurement of lathe check depth and the grain angle of birch (Betula pendula Roth) veneers using laser transillumination imaging. Wood Sci Technol 49:591-605 
Ashby MF, Easterling KE, Harrysson R, Maiti SK (1985) The fracture and toughness of woods. Proc Roy Soc 398:261-280

Blomqvist L, Sandberg D, Johansson J (2014) Influence of veneer orientation on shape stability of plane laminated veneer products. Wood Mat Sci Eng 9:224-232

Boatright SWJ, Garrett GG (1983) The effect of microstructure and stress state on the fracture behaviour of wood. J Mater Sci 18:2181-2199

Buchelt B, Wagenführ A, Dietzel A, Raßbach H (2018) Quantification of cracks and cross-section weakening in sliced veneers. Eur J Wood Prod, 76:381-384

Darmawan W, Nandika D, Massijaya Y, Kabe A, Rahayu I, Denaud L, Ozarska B (2015) Lathe check characteristics of fast growing sengon veneers and their effect on LVL glue-bond and bending strength. J Mater Process Tech 215:181-188

Denaud LÉ, Bléron L, Eyma F, Marchal R (2012) Wood peeling process monitoring: A comparison of signal processing methods to estimate veneer average lathe check frequency. Eur $\mathrm{J}$ Wood Prod 70:256-261

Denaud LÉ, Bléron, L, Ratle A, Marchal R (2007) Online control of wood peeling process: acoustical and vibratory measurements of lathe checks frequency. Ann Forest Sci 64:569-575

Dupleix A, Denaud LÉ, Bléron L, Marchal R, Hughes M (2013) The effect of log heating temperature on the peeling process and veneer quality: beech, birch, douglas-fir and spruce case studies. Eur J Wood Prod 71:163-171

Leney L (1960) A photographic study of veneer formation. Forest Prod J 10:133-139

Lutz JF (1960) Heating veneer bolts to improve quality of Douglas-fir plywood. US For. Prod. Lab. Rep. No 2182, Madison, Wise.

Lutz JF (1974) Techniques for Peeling, Slicing, and Drying Veneer. US For. Prod. Lab. Rep. No 228, Madison, Wise.

Lutz JF (1978) Wood veneer: Log selection, cutting, and drying. US For. Prod. Lab. Rep. No 1577, Madison, Wise.

Marchal R, Mothe F, Denaud LE, Thibaut B, Bléron L (2009) Cutting forces in wood machiningbasics and applications in industrial processes. A review COST Action E35 2004-2008: wood machining-micromechanics and fracture. Holzforschung 63:157-167

McMillin CW (1958) The relation of mechanical properties of wood and nosebar pressure in the production of veneer. Forest Prod J 8:23-32 
Meriluoto J (1965) The Influence of Raw Material Factors on the Quantity and Quality of Rotary Cut Brick Veneer. Acta Forestalia Fennica, 80:1-155

Pot G, Denaud LE, Collet R (2015) Numerical study of the influence of veneer lathe checks on the elastic mechanical properties of laminated veneer lumber (LVL) made of beech. Holzforschung, 69:337-345

Pałubicki B, Marchal R, Butaud JC, Denaud LE, Bléron L, Collet R, Kowaluk G (2010) A Method of Lathe Checks Measurement; SMOF device and its software. Eur J Wood Prod 68:151-159

Rohumaa A, Antikainen T, Hunt CG, Frihart CR, Hughes M (2016a) The influence of log soaking temperature on surface quality and integrity performance of birch (Betula pendula Roth) veneer. Wood Sci Technol 50:463-474

Rohumaa A, Yamamoto A, Hunt CG, Frihart CR, Hughes M, Kers J (2016b). Effect of log soaking and the temperature of peeling on the properties of rotary-cut birch (Betula pendula Roth) veneer bonded with phenol-formaldehyde adhesive. BioResources 11:5829-5838

Rohumaa A, Hunt CG, Frihart CR, Saranpää P, Ohlmeyer M, Hughes M (2014) The influence of felling season and log-soaking temperature on the wetting and phenol formaldehyde adhesive bonding characteristics of birch veneer. Holzforschung 68:965-970

Rohumaa A, Hunt CG, Hughes M, Frihart CR, Logren J. (2013) The influence of lathe check depth and orientation on the bond quality of phenol-formaldehyde-bonded birch plywood. Holzforschung 67:779-786

Sellers T (1985) Plywood and adhesive technology. CRC Press.

Spelter H (1991) Recent developments in veneer peeling confront quality variables. Panel World 5:54-65.

Tomppo L, Tiitta M, Lappalainen R (2009) Ultrasound evaluation of lathe check depth in birch veneer. Eur J Wood Prod 67:27-35. 
Table 1 Experimental design

\begin{tabular}{lccccc}
\hline & Trials & $\begin{array}{c}\text { Cutting } \\
\text { speed } \\
(\mathbf{m} / \mathbf{s})\end{array}$ & $\begin{array}{c}\text { Soaking } \\
\text { temperature } \\
\left({ }^{\circ} \mathbf{C}\right)\end{array}$ & $\begin{array}{c}\text { Compression } \\
\text { rate (\%) }\end{array}$ & $\begin{array}{c}\text { Veneer } \\
\text { thickness } \\
(\mathbf{m m})\end{array}$ \\
\hline Cutting speed and radius & $a$ & 1 & 70 & 0 & 3,5 \\
& $b$ & 2 & 70 & 0 & 3,5 \\
Soaking temperature & $c$ & 3 & 70 & 0 & 3,5 \\
and compression rate & 1 & 2 & 50 & 0 & 3,5 \\
& 2 & 2 & 50 & 5 & 3,5 \\
& 3 & 2 & 50 & 10 & 3,5 \\
& 4 & 2 & 50 & 15 & 3,5 \\
& 6 & 2 & 60 & 0 & 3,5 \\
& 5 & 2 & 60 & 5 & 3,5 \\
& 7 & 2 & 60 & 10 & 3,5 \\
& 8 & 2 & 60 & 15 & 3,5 \\
& 10 & 2 & 70 & 0 & 3,5 \\
& 9 & 2 & 70 & 5 & 3,5 \\
& 11 & 2 & 70 & 10 & 3,5 \\
& 12 & 2 & 70 & 15 & 3,5 \\
& 14 & 2 & 80 & 0 & 3,5 \\
& 13 & 2 & 80 & 5 & 3,5 \\
& 15 & 2 & 80 & 10 & 3,5 \\
16 & 2 & 80 & 15 & 3,5 \\
\hline
\end{tabular}




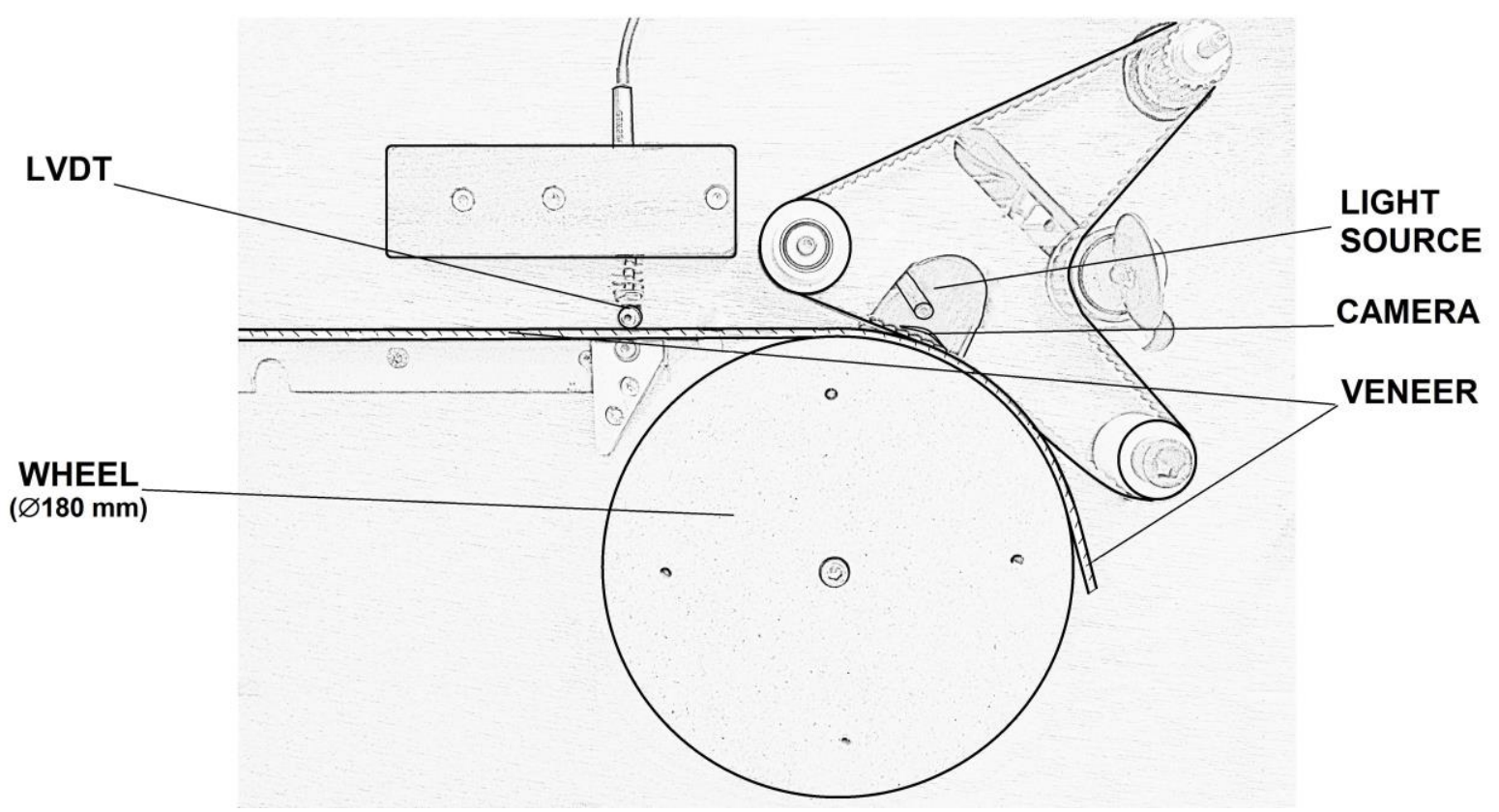

Fig. 1 SMOF, optical lathe check measuring system. LVDT is the linear variable differential transformer. 


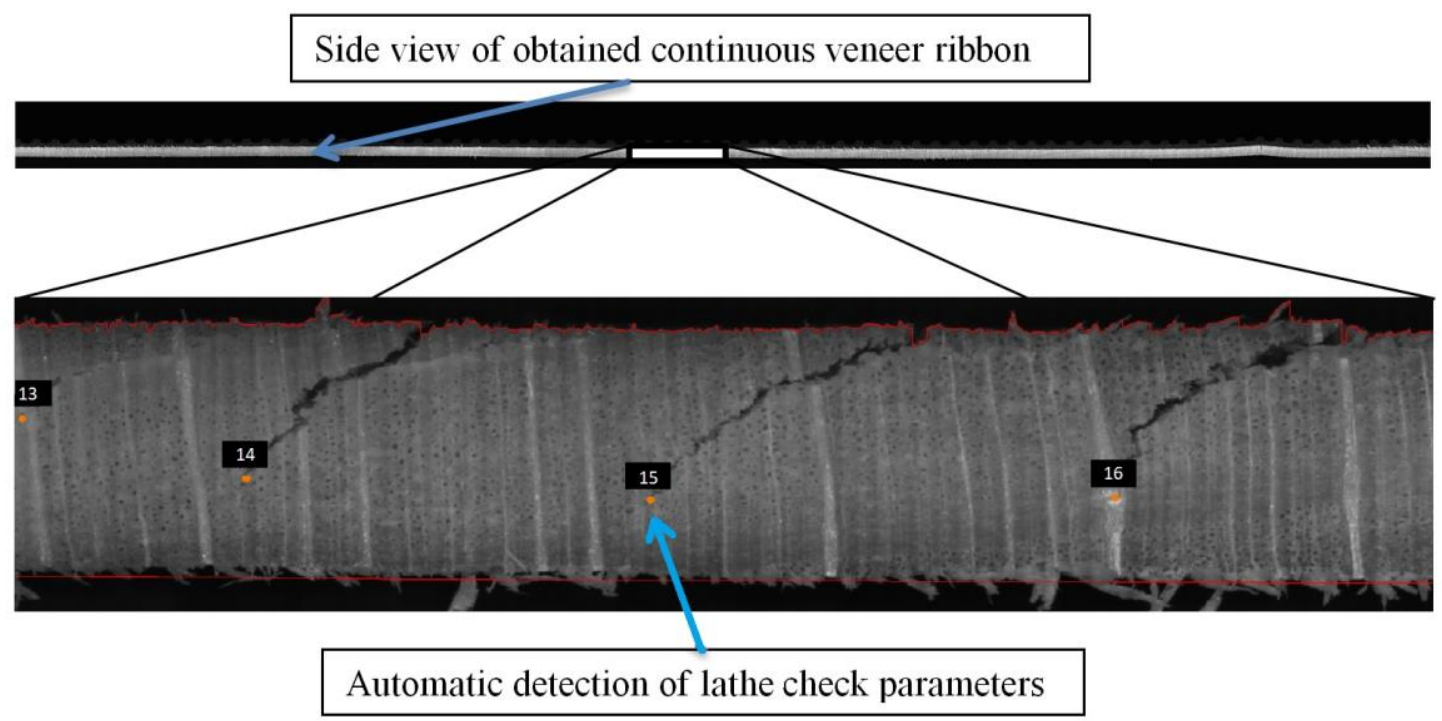

Fig. 2 Side view of obtained veneer ribbon and lathe check detection $\left(t=60^{\circ} \mathrm{C}\right.$, without pressure bar) 
a)

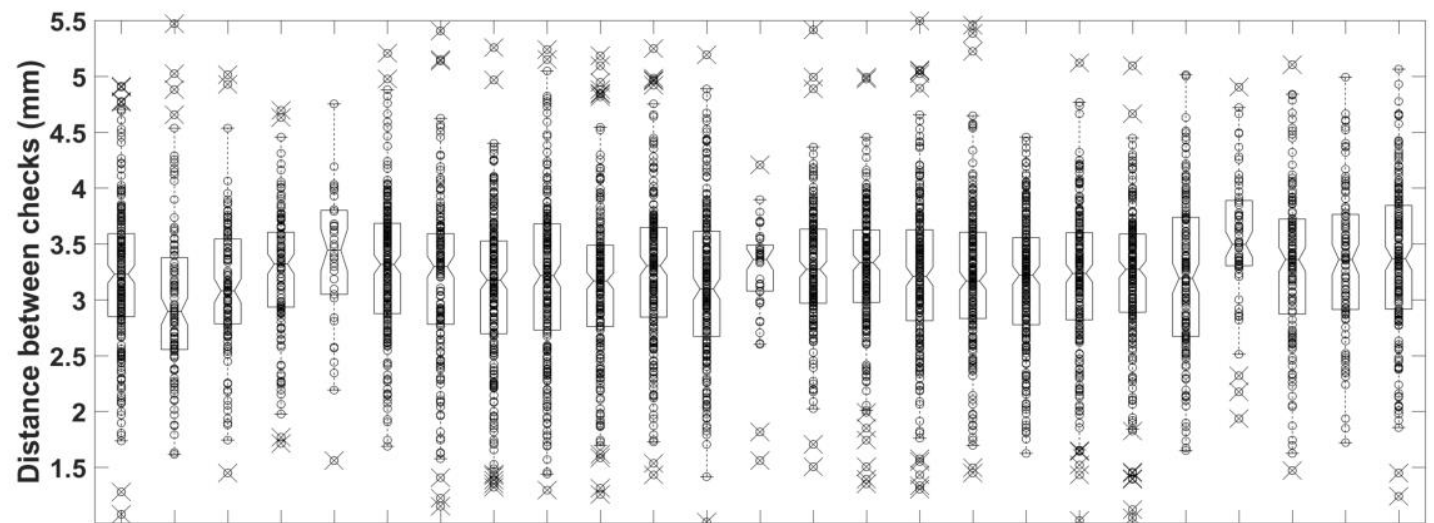

b)

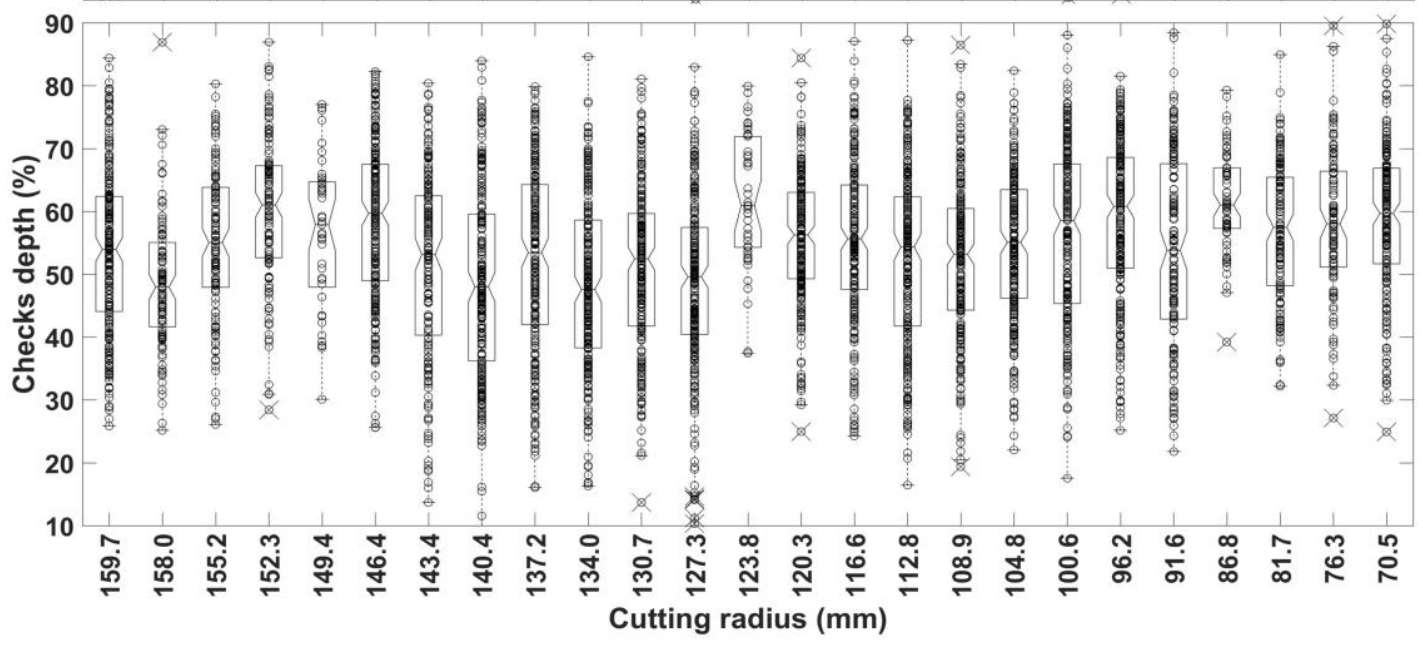

Fig. 3 a) Lathe check interval and b) lathe check depth according to the cutting radius 
a)

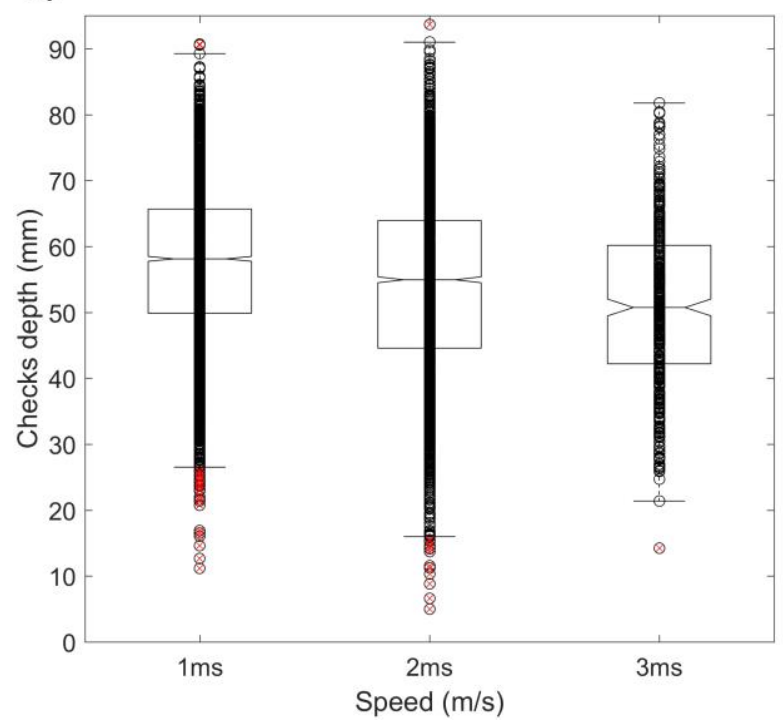

b)

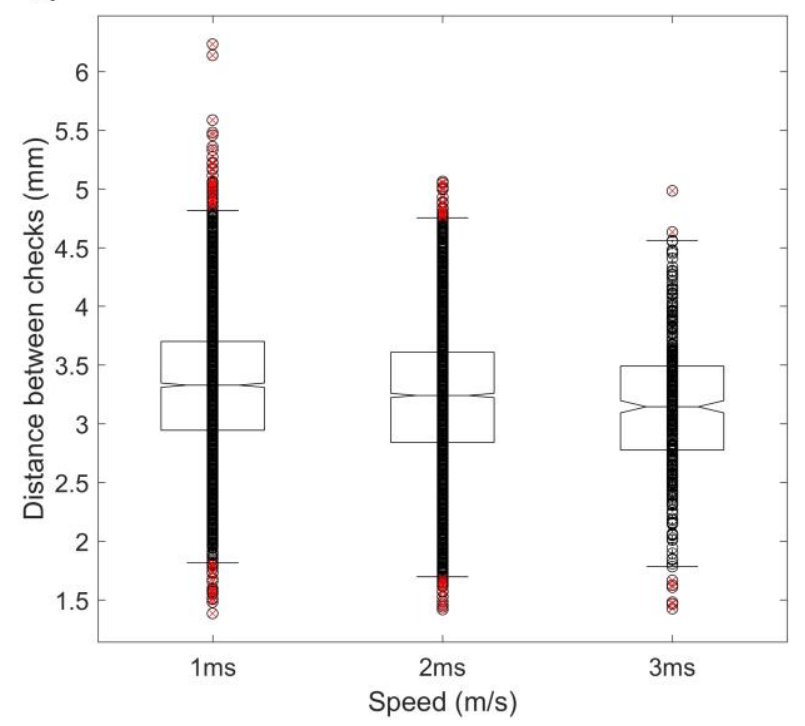

Fig. 4 The effect of cutting speed on a) lathe check depth and b) distance between checks 
a)
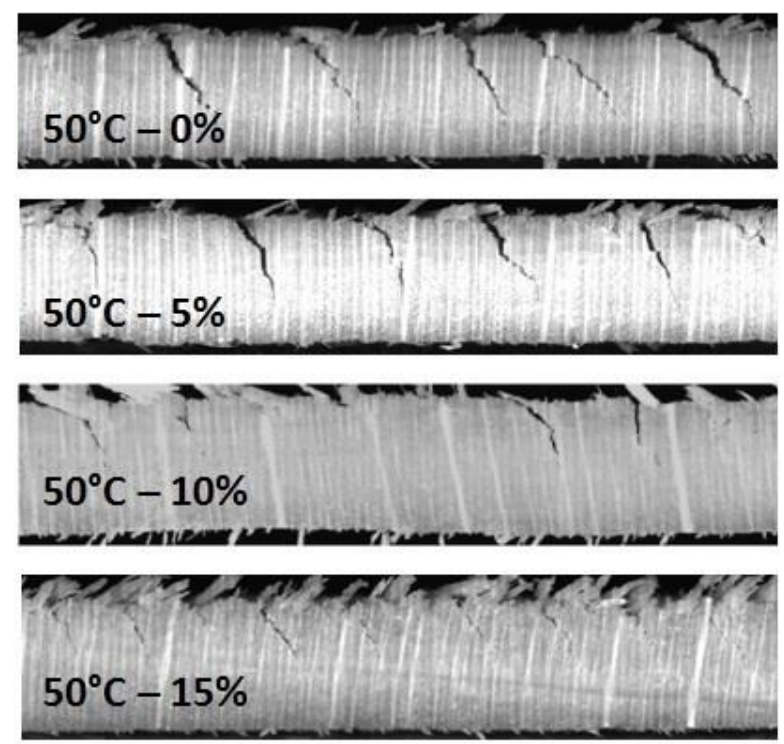

b)
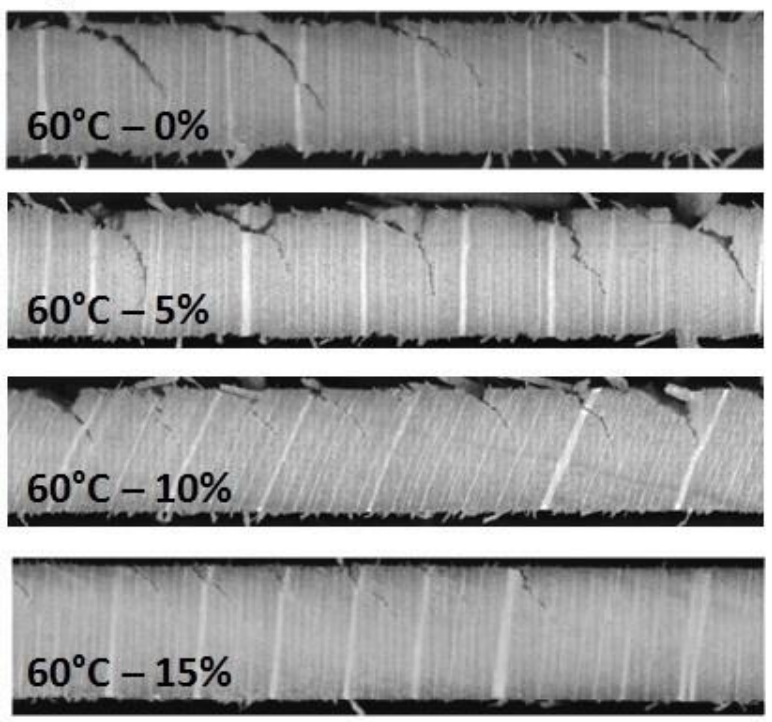

c)
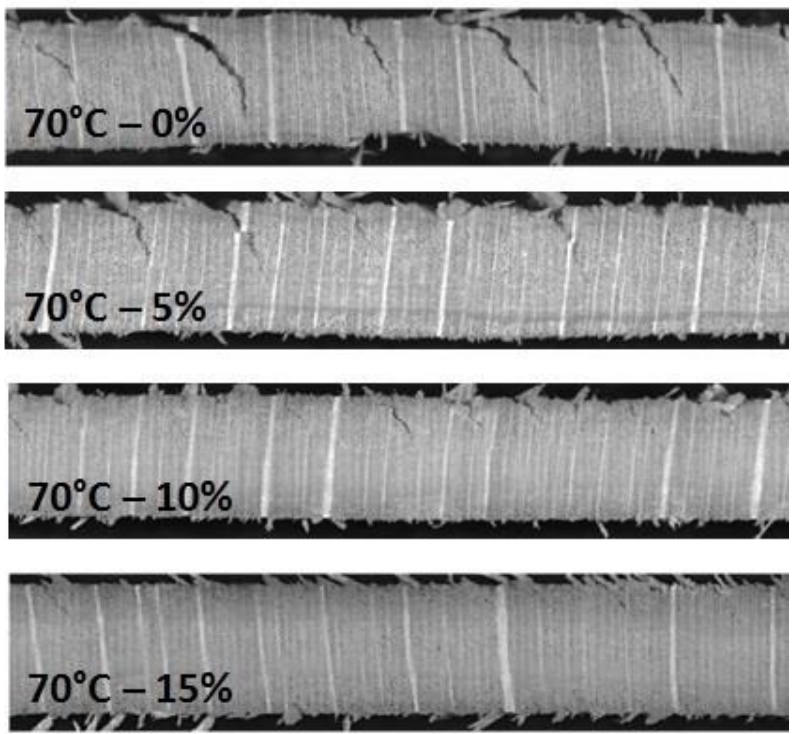

d)
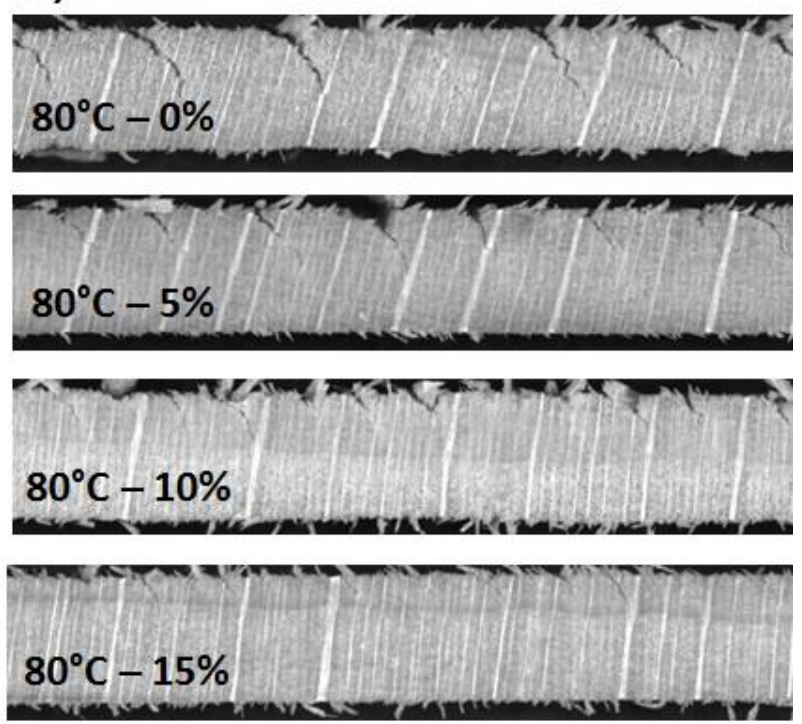

Fig. 5 Effect of soaking temperature and compression rate on lathe check properties (camera images from the SMOF). Where the compression rate varies from $0 \%$ to $15 \%$ of the veneer thickness for a) soaking at $50^{\circ} \mathrm{C}, \mathrm{b}$ ) soaking at $60^{\circ} \mathrm{C}, \mathrm{c}$ ) soaking at $70^{\circ} \mathrm{C}, \mathrm{d}$ ) soaking at $80^{\circ} \mathrm{C}$. 


\section{a)}

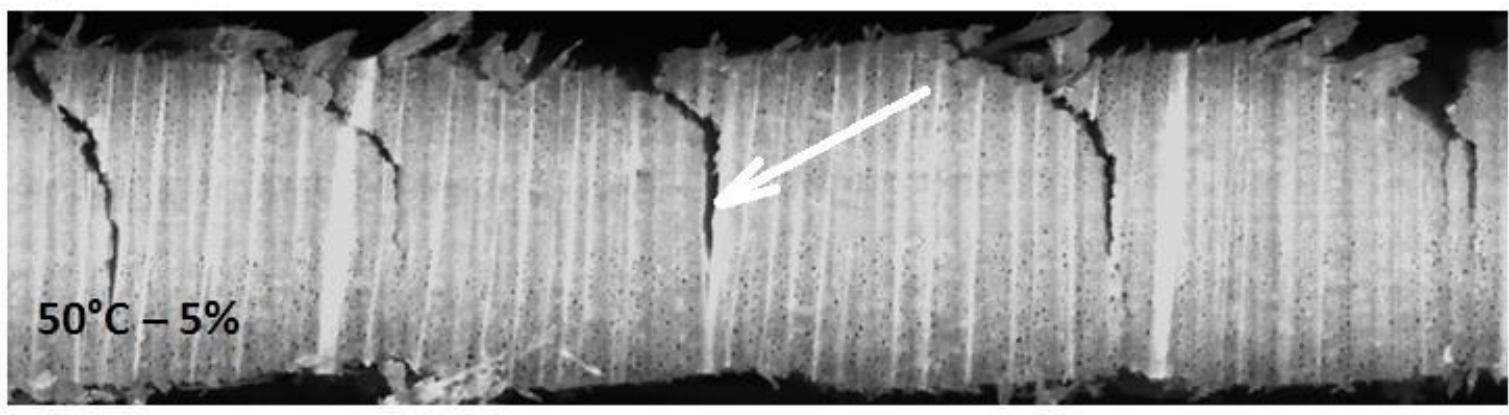

b)

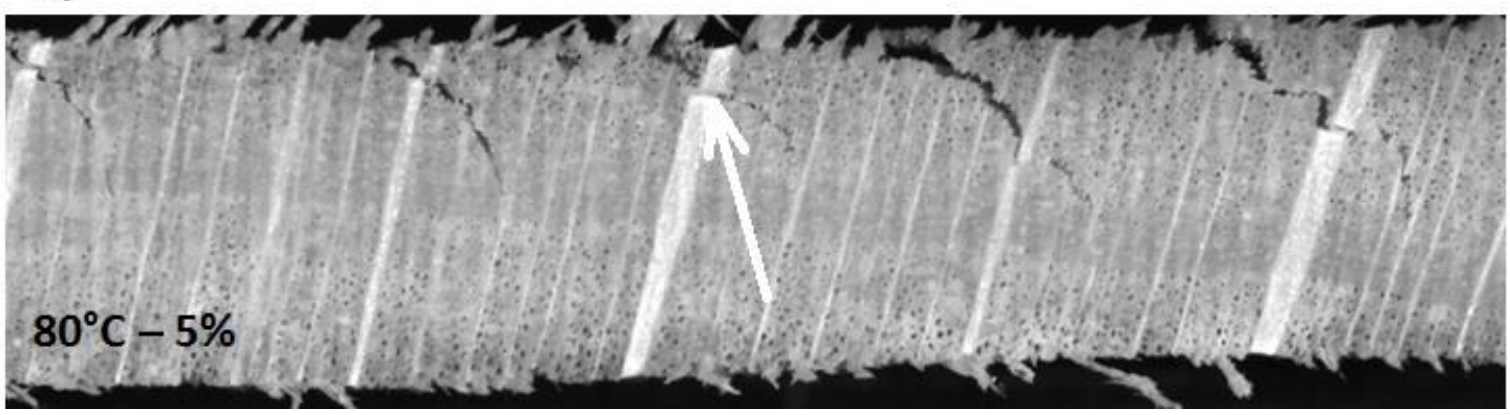

Fig. 6 Effect of temperature on lathe check propagation. Arrows show check propagation a) along and b) through the ray 


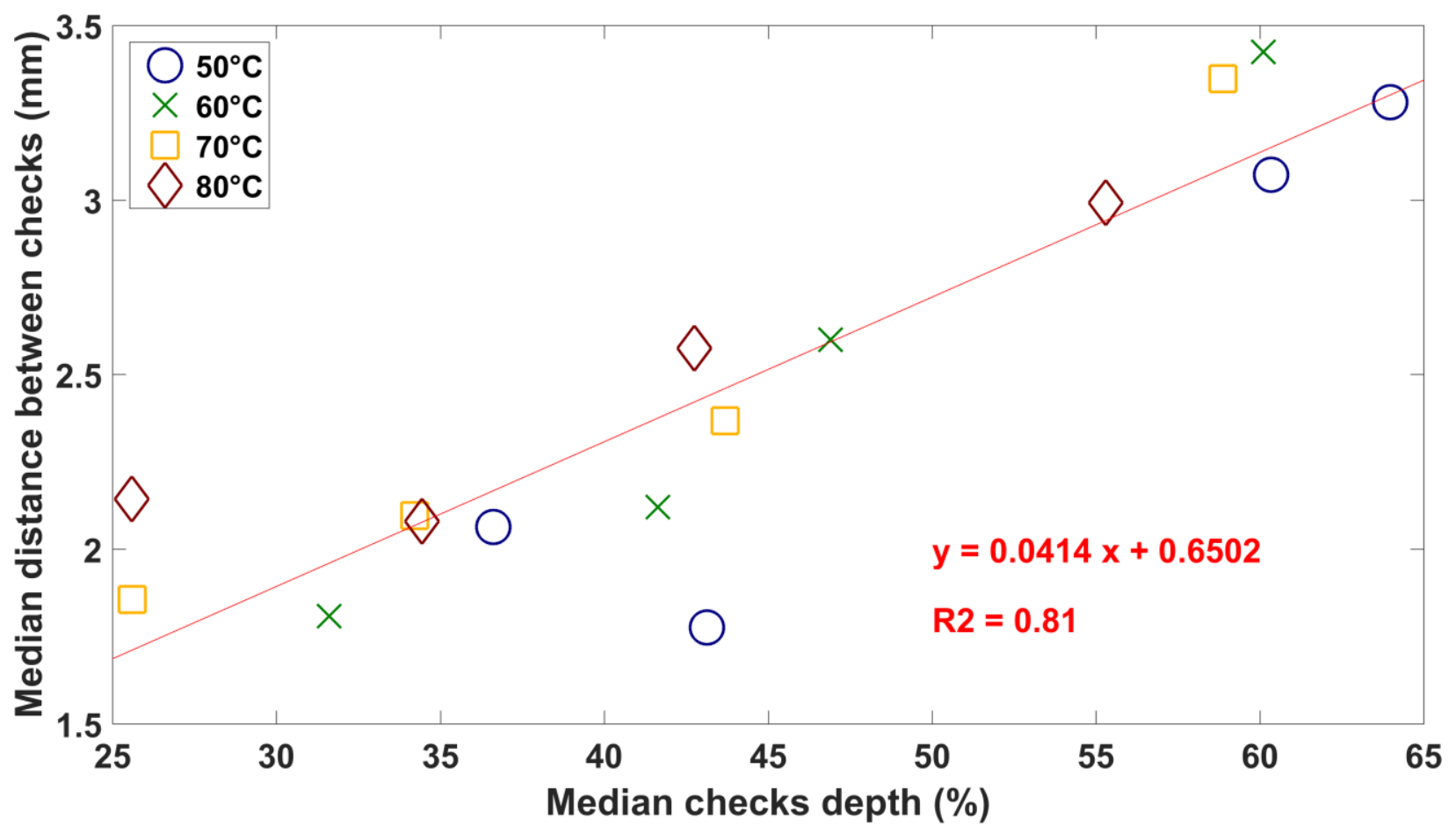

Fig. 7 Relationship between median check interval and median check depth. 

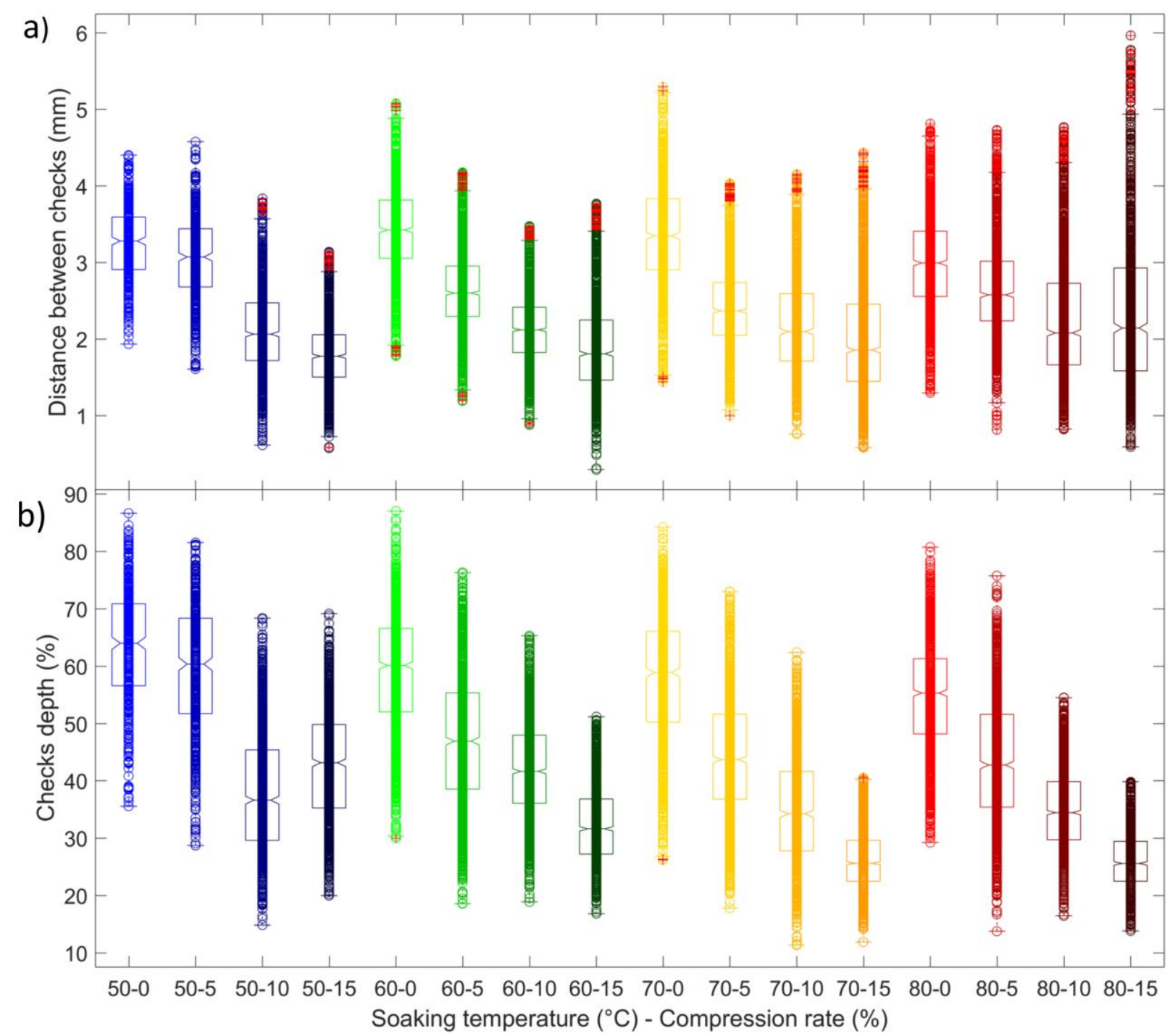

Fig. 8 Effect of soaking temperature and compression rate on lathe check a) interval and b) depth (boxplot and distribution of checks) 